\title{
Can Alpha-1 Antitrypsin Levels be Used to Predict the Prognosis of COVID-19 Therapy?
}

\section{Alfa-1 Antitripsin Düzeyleri COVID-19Tedavisinin Prognozunu Öngörmek için Kullanılabilir mi?}

\author{
(D) Elif ARAS ATIK*, (D) Nesligül ÖZDEMIR, (D) Kutay DEMIRKAN \\ Hacettepe University Faculty of Pharmacy, Department of Clinical Pharmacy, Ankara, Turkey
}

Key words: COVID-19, alpha-1 antitrypsin, treatment

Anahtar kelimeler: COVID-19, alfa-1 antitripsin, tedavi

\section{Dear Editor,}

The Coronavirus Disease-2019 (COVID-19) outbreak began to spread in China in December 2019 and was recognized as a pandemic by the World Health Organization in March 2020. The COVID-19 outbreak causes acute respiratory distress in patients and increases the need for intensive care. Smoking, advanced age, and comorbid diseases can be risk factors for COVID-19. In smokers, a 1.4-fold higher risk of serious symptoms and a 2.4-fold higher risk of mechanical ventilation and intensive care needs were determined.

No parameter has yet been discovered that could predict the exact prognosis of COVID-19.

Alpha-1 antitrypsin (AAT) is a very common serine protease inhibitor that exists in plasma. Its main function is to protect lung cells from proteolytic damage by neutrophil elastase. ${ }^{2}$ AAT is constantly present in the serum of healthy individuals (20$52 \mu \mathrm{mol} / \mathrm{L}$ ) and the concentration may increase several times during inflammation. ${ }^{2,3}$ AAT is an acute phase reactant as well as an anti-inflammatory, immunomodulatory, anti-infective, and tissue repair molecule. ${ }^{4}$

AAT deficiency is an inherited disorder that can cause liver and lung diseases. Due to insufficient function of AAT, neutrophil elastase destroys alveoli and causes lung disease. AAT deficiency is seen ( 1 in every 1,500-3,500 people) worldwide, but its frequency varies according to populations. ${ }^{4}$ AAT deficiency has not yet been diagnosed in many individuals. Environmental factors such as smoking, chemicals, and exposure to dust affect the severity of AAT deficiency. People who have AAT deficiency usually develop symptoms of lung disease between the ages of 20 and 50 . The risk of lung disease seems to be most clinically important when serum levels of AAT are less than $11 \mu \mathrm{mol} / \mathrm{L} .{ }^{5}$ Generally, the first symptoms are shortness of breath during exercise, decreased exercise ability, and wheezing. Unintended weight loss, recurrent respiratory infections, emphysema, weakness, and tachycardia can be seen in this group of patients. Smoking and exposure to tobacco products accelerate lung damage and emphysema symptoms. ${ }^{6}$

There are studies in the literature showing that AAT levels can be associated with different situations. ATT has significant anti-inflammatory and immunoregulatory effects that may be associated with human immunodeficiency virus (HIV) in addition to its effects on the lungs. ${ }^{2}$ Functional deficiency of AAT may contribute to the development of emphysema in HIVpositive patients. ${ }^{7}$

In COVID-19 patients it is found that there is a hyperinflammatory response that affects disease severity and mortality. In particular, chronic obstructive pulmonary disease patients and smokers are more vulnerable to the effects of COVID-19. ${ }^{8}$

*Correspondence: E-mail: eczelifaras@gmail.com, Phone: +90 5377893189 ORCID-ID: orcid.org/0000-0001-8667-6623

Received: 31.08.2020, Accepted: 13.09.2020

๑Turk J Pharm Sci, Published by Galenos Publishing House. 
In conclusion, we would like to state that AAT levels, which are accepted as an acute phase reactant, should be evaluated in patients with COVID-19 to determine whether deficiency of AAT is the underlying reason for the poor course of COVID-19 in smokers and in patients with lung diseases. There has been no established study evaluating AAT levels in COVID-19 patients. The bad prognosis of the disease and increased need for mechanical ventilation in COVID-19 patients may be related to AAT levels. This specific protein should be considered a predictive factor in COVID-19 patients with a bad prognosis. In addition, intravenous augmentation therapy with purified human AAT is available for AAT deficiency to prevent lung destruction and stabilize the disease ${ }^{9}$ and this treatment may be beneficial in COVID-19 patients as well.

Conflicts of interest: No conflict of interest was declared by the authors. The authors alone are responsible for the content and writing of the paper.

\section{REFERENCES}

1. Vardavas $\mathrm{Cl}$, Nikitara K. COVID-19 and smoking: A systematic review of the evidence. Tob Induc Dis. 2020;18:20.

2. Thudium RF, Lundgren J, Benfield T, Nordestgaard BG, Borges $A H$, Gerstoft J, Nielsen SD, Ronit A. HIV infection is independently associated with a higher concentration of alpha-1 antitrypsin. HIV Med. 2018;19:745-750.

3. Brantly M, Nukiwa T, Crystal RG. Molecular basis of alpha-1-antitrypsin deficiency. Am J Med. 1988;84:13-31.

4. de Serres F, Blanco I. Role of alpha-1 antitrypsin in human health and disease. J Intern Med. 2014:276:311-335.

5. Crystal RG. Alpha 1-antitrypsin deficiency, emphysema, and liver disease. Genetic basis and strategies for therapy. J Clin Invest. 1990;85:1343-1352.

6. Salvi S. Tobacco smoking and environmental risk factors for chronic obstructive pulmonary disease. Clin Chest Med. 2014;35:17-27.

7. Stephenson SE, Wilson CL, Crothers K, Attia EF, Wongtrakool C, Petrache I, Schnapp LM. Impact of HIV infection on $\alpha 1$-antitrypsin in the lung. Am J Physiol Lung Cell Mol Physiol. 2018;314:L583-L592.

8. Leung JM, Yang CX, Tam A, Shaipanich T, Hackett TL, Singhera GK, Dorscheid DR, Sin DD. ACE-2 expression in the small airway epithelia of smokers and COPD patients: implications for COVID-19. Eur Respir J. 2020;55:2000688

9. Brode SK, Ling SC, Chapman KR. Alpha-1 antitrypsin deficiency: a commonly overlooked cause of lung disease. CMAJ. 2012;184:13651371. 